\title{
О СОДЕРЖАНИИ ПОЛИХЛОРИРОВАННЫХ БИФЕНИЛОВ И ХЛОРОРГАНИЧЕСКИХ ПЕСТИЦИДОВ В РЫБАХ БАЛТИЙСКОГО МОРЯ
}

O. ROOTS, Edda PEIKRE. POLOKLOREERITUD BIFENUOLIDE JA KLOORORGAANIDE PESTIT. SIIDIDE SISALDUSED LÅANEMERE KALADES

O. ROOTS, Edda PEIKRE. POLYCHLORINATED AND CHLORINATED PESTICIDES IN THE BALTIC FISH

Постоянное накопление в морях и океанах хлорорганических соединений представляет в настоящее время серьезную экологическую проблему. Относительная химическая устойчивость этих соединений, а также способность к миграции обусловливают их распространение в морской среде. Накапливающиеся в гидробионтах полихлорированные бифенилы (ПХБ) и хлорорганические пестициды (ХОП) по трофической цепи попадают в организм человека. Определение их при анализе гидробионтов, несомненно, необходимо.

В 1975 г. мы приступили к изучению распространенности указанных соединений в морских организмах (рыбах, моллюсках и т. п.). Впервые были получены данные о содержании ПХБ и ХОП в морских организмах Балтийского моря (акватория Советского Союза).

Многими авторами указывается, что пелагические рыбы, питающиеся морским планктоном, служат хорошим «индикатором» при определении загрязнения морей ПХБ и ХОП $[3,10]$. Для Балтийского моря такой рыбой является салака, распространенная по всей его акватории отдельными локальными популяциями (принимаются во внимание также отдельные биологические расы и географические группы) [4,5].

Нами анализировалась весенне-нерестующая салака (более 230 особей), отловленная пелагическим тралом в водах Финского залива и открытой части Бал-

$A$ - хроматограмма стандартного раствора ПХБ (хлофен А50), Б - хроматограмма экстракта пробы салаки после обработки $10 \%$-ным раствором щелочи в метаноле.

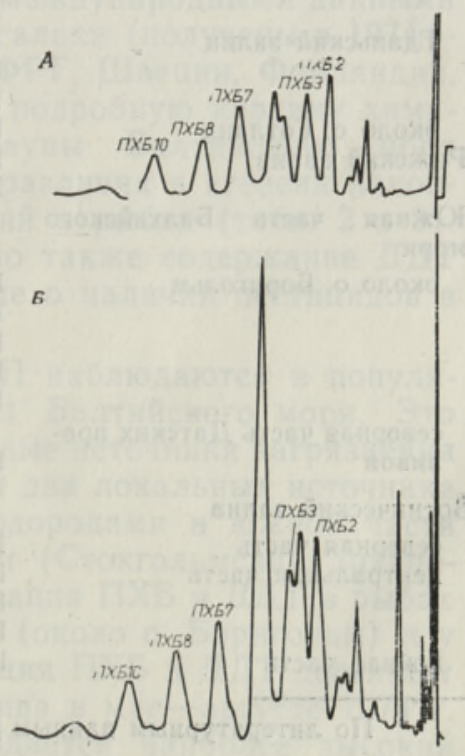


тийского моря (конец апреля - май 1975 и 1976 гг.). При анализе мы пользовались комплексной методикой экстракции и очистки хлорорганичеоких соединений с последующей газохроматографией для раздельного определения ПХБ и ХОП, разработанной сектором морской химии Института термофизики и электрофизики АН ЭССР [6]. Хроматограммы стандартного раствора ПХБ (хлофен А50) и экстракта пробы салаки, предварительно обработанной 10\%-ным раствором

Таблица 1

Содержание ПХБ и ХОП в мышечной ткани весенне-нерестующей салаки (сельди) по всей акватории Балтийского моря

\begin{tabular}{|c|c|c|c|c|c|c|c|}
\hline \multirow{2}{*}{$\begin{array}{c}\text { Местообитание } \\
\text { популяции }\end{array}$} & \multirow{2}{*}{$\begin{array}{l}\text { Время } \\
\text { иссле- } \\
\text { цований }\end{array}$} & \multirow{2}{*}{$\begin{array}{c}\text { Возраст } \\
\text { рыб, } \\
2 .\end{array}$} & \multirow{2}{*}{$\begin{array}{l}\text { Коли- } \\
\text { чество } \\
\text { особей }\end{array}$} & \multicolumn{4}{|c|}{ Содержание, мг/кг сырого веса } \\
\hline & & & & ПХБ & $\begin{array}{l}\text { п, П П' } \\
\text { ДДЕ }\end{array}$ & $\begin{array}{l}\text { п, п् } \\
\text { ДДд }\end{array}$ & $\begin{array}{l}\text { п, п' } \\
\text { ДДТ }\end{array}$ \\
\hline \multicolumn{8}{|l|}{ Финский залив } \\
\hline восточная часть & 1975 & $2-4$ & 8 & 0,14 & 0,10 & 0,08 & 0,10 \\
\hline & 1975 & & 22 & 0,20 & 0,10 & 0,12 & 0,04 \\
\hline западная часть & 1975 & $2-4$ & 11 & 0,02 & 0,07 & 0,09 & 0,04 \\
\hline & $\begin{array}{l}1975 \\
1974 *\end{array}$ & $>4$ & $\begin{array}{r}75 \\
8\end{array}$ & 0,24 & 0,15 & 0,07 & 0,06 \\
\hline & $\begin{array}{l}19 / 4^{*} \\
1974^{*}\end{array}$ & $2-8$ & 10 & 0,14 & $\begin{array}{l}0,03 \\
0,06\end{array}$ & $\begin{array}{l}0,03 \\
0,05\end{array}$ & $\begin{array}{l}0,03 \\
0,04\end{array}$ \\
\hline центральная часть & $1974^{*}$ & $1-4$ & 16 & 0,20 & 0,05 & 0,03 & 0,03 \\
\hline \multicolumn{8}{|l|}{$\begin{array}{l}\text { Открытая часть Балтийского } \\
\text { моря }\end{array}$} \\
\hline $\begin{array}{l}\text { от Вентспилса до о. Саaре- } \\
\text { маа }\end{array}$ & 1975 & $2-4$ & 14 & 0,07 & 0,06 & 0,06 & 0,01 \\
\hline & 1975 & $>4$ & 8 & 0,30 & 0,10 & 0,09 & $\begin{array}{l}0,01 \\
0,06\end{array}$ \\
\hline & 1976 & $2-3$ & 5 & 0,29 & 0,05 & 0,03 & 0,02 \\
\hline & 1976 & & 5. & 0,33 & 0,10 & 0,09 & 0,08 \\
\hline \multirow{5}{*}{$\begin{array}{l}\text { западное побережье о. Саa- } \\
\text { ремаa }\end{array}$} & 1976 & & 5 & 0,38 & 0,27 & 0,23 & 0,22 \\
\hline & 1976 & $2-3$ & 15 & 0,17 & 0,05 & 0,05 & 0,03 \\
\hline & 1976 & & 10 & 0,24 & 0,10 & 0,08 & 0,06 \\
\hline & 1976 & $5-6$ & 6 & 0,42 & 0,16 & 0,11 & 0,09 \\
\hline & 1976 & 7 & 5 & 0,33 & 0,17 & 0,11 & 0,08 \\
\hline $\begin{array}{l}\text { побережье Лиепая - Клай- } \\
\text { педа }\end{array}$ & 1976 & $1-2$ & 7 & 0,42 & 0,11 & 0,09 & 0,06 \\
\hline \multirow{3}{*}{ Гданьскнй залив } & $\begin{array}{l}1976 \\
1974 *\end{array}$ & 6 & 2 & 0,99 & 0,06 & 0,04 & 0,02 \\
\hline & $\begin{array}{l}1974^{*} \\
1974^{*}\end{array}$ & $\begin{array}{l}\text { миним. } \\
\text { макс. }\end{array}$ & - & $\begin{array}{l}0,35 \\
2,10\end{array}$ & $\begin{array}{l}0,06 \\
0,70\end{array}$ & $\begin{array}{l}0,49 \\
1,50\end{array}$ & $\begin{array}{l}0,20 \\
1,70\end{array}$ \\
\hline & $1974^{*}$ & средн. & - & 0,41 & 0,51 & 0,14 & 0,35 \\
\hline \multirow{3}{*}{ Рижский залив } & $1974^{*}$ & $3-8$ & 10 & 0,45 & 0,21 & 0,12 & 0,15 \\
\hline & 1975 & 2 & 5 & 0,01 & 0,03 & 0,04 & 0,01 \\
\hline & 1975 & $2-4$ & 10 & 0,16 & 0,05 & 0,07 & 0,03 \\
\hline $\begin{array}{l}\text { Южная часть Балтийского } \\
\text { моря }\end{array}$ & & & & & & & \\
\hline \multirow[t]{5}{*}{ около о. Борнгольм } & $1974^{*}$ & до 1 & 19 & 0,31 & 0,07 & 0,06 & 0,25 \\
\hline & $1974^{*}$ & & 5 & 0,37 & 0,10 & 0,06 & 0,10 \\
\hline & $1975^{*}$ & $2-3$ & 10 & 0,43 & 0,31 & 0,10 & 0,20 \\
\hline & $1974^{*}$ & $3-4$ & 11 & 0,56 & 0,21 & 0,10 & 0,19 \\
\hline & $1974^{*}$ & $5-6$ & 8 & 0,79 & 0,52 & 0,18 & 0,44 \\
\hline $\begin{array}{l}\text { северная часть Датских про- } \\
\text { ливов }\end{array}$ & $1975^{*}$ & $2-3$ & 20 & 0,42 & 0,10 & 0,06 & 0,12 \\
\hline \multicolumn{8}{|l|}{ Ботнический залив } \\
\hline северная часть & $1974^{*}$ & $1-3$ & 10 & 0,10 & 0,02 & $\overline{0} 07$ & 0,003 \\
\hline центральная часть & $\begin{array}{l}1975^{*} \\
1974^{*}\end{array}$ & $\begin{array}{l}2-4 \\
3-5\end{array}$ & $\begin{array}{r}5 \\
10\end{array}$ & $\begin{array}{l}0,18 \\
0,27\end{array}$ & $\begin{array}{l}0,04 \\
0,09\end{array}$ & $\begin{array}{l}0,007 \\
0,03\end{array}$ & $\begin{array}{l}0,04 \\
0,06\end{array}$ \\
\hline & $1975^{*}$ & 7 & 5 & 0,85 & 0,46 & 0,02 & 0,14 \\
\hline южная часть & $1974^{*}$ & до 3 & 10 & 0,14 & 0,02 & 0,02 & 0,02 \\
\hline
\end{tabular}

* По литературным данным [1, 2]. 
таблица 2

Содержание ПХБ в мышечной ткани весенне-нерестующей салаки по отдельным возрастным группам (открытая часть Балтийского моря)

\begin{tabular}{|c|c|c|c|c|c|}
\hline \multirow{2}{*}{$\begin{array}{c}\text { Местообитание } \\
\text { популящии }\end{array}$} & \multicolumn{5}{|c|}{$\begin{array}{c}\text { Содержание ПХБ по отдельным возрастным } \\
\text { группам, мг/кг сырого веса }\end{array}$} \\
\hline & $\begin{array}{l}1-2 \\
\text { года }\end{array}$ & 3 года & 4 года & $5-6$ лет & $\begin{array}{l}7 \text { лет и } \\
\text { выше }\end{array}$ \\
\hline $\begin{array}{l}\text { Северо-западное побережье о. } \\
\text { Сааремаа } \\
\text { От Вентспилса до о. Сааремаа } \\
\text { Побережье Лиепая - Клайпеда }\end{array}$ & $\begin{array}{l}0,16 \\
0,25 \\
0,42\end{array}$ & $\begin{array}{l}0,19 \\
0,35 \\
0,99\end{array}$ & $\begin{array}{l}0,24 \\
0,33 \\
-\end{array}$ & $\begin{array}{l}0,42 \\
0,38 \\
-\end{array}$ & $\frac{0,33}{-}$ \\
\hline
\end{tabular}

таблица 3

Средние содержания хлорорганических соединений в мышечной ткани весенне-нерестующей салаки (открытая часть

Балтийского моря, весна-осень 1976 г.)

\begin{tabular}{|c|c|c|c|c|c|c|}
\hline \multirow{2}{*}{ Возраст рыб, г. } & \multirow{2}{*}{$\begin{array}{l}\text { Количе- } \\
\text { ство } \\
\text { особей }\end{array}$} & \multirow{2}{*}{ Сезон } & \multicolumn{4}{|c|}{ Среднее содержание, мг/ка сырого веса } \\
\hline & & & ПХБ & п, п' ДДЕ & п, п' ддд & п, п' Ддт \\
\hline \multirow[t]{2}{*}{$1-2$} & 7 & весна & 0,16 & 0,04 & 0,04 & 0,03 \\
\hline & 14 & осень & 0,28 & 0,05 & 0,04 & 0,03 \\
\hline \multirow[t]{2}{*}{$3-4$} & 17 & весна & 0,22 & 0,08 & 0,07 & 0,05 \\
\hline & 9 & осень & 0,32 & 0,10 & 0,08 & 0,06 \\
\hline \multirow[t]{2}{*}{5 и старше } & 9 & весна & 0,39 & 0,16 & 0,17 & 0,09 \\
\hline & 5 & осень & 0,57 & 0,07 & 0,05 & 0,03 \\
\hline
\end{tabular}

щелочи в метаноле для разложения пестицидов, представлены на рисунке. Содержание ПХБ определялось суммированием пиков $2,3,7,8$, 10 (см. рисунок, $A$ и $Б$ ) [ [11].

Сравнение результатов наших анализов с международными данными $\left[{ }^{1,2}\right]$ о содержании токсикантов в организмах салаки (получены в $1974-$ 1975 гг. в пяти прибалтийских странах - ФРГ, Швеции, Финляндии, Дании и Польше) позволило получить более подробную картину химического загрязнения промысловой ихтиофауны Балтийского моря (табл. 1). Выявлены возрастные и сезонные различия в степени накопления некоторых хлорорганических соединений в рыбах (табл. 2 и 3). Поскольку при определении ПХБ установлено также содержание ДДТ и его метаболитов, нами приводятся и данные о наличии пестицидов в мышечной ткани рыб (табл. 3).

Самые высокие концентрации ПХБ и ХОП наблюдаются в популяциях салаки центрального и южного районов Балтийского моря. Это обусловлено тем, что здесь расположены главные источники загрязнения моря указанными токсикантами. Обнаружены два локальных источника загрязнения моря хлорорганическими углеводородами в южной части моря (Гданьский залив) и в открытой части (Стокгольмский архипелаг) $\left[{ }^{7,9}\right.$. Этим объясняется высокая концентрация ПХБ и ДДТ в рыбах самого залива, а также в южной части моря (около о. Борнгольм) и у побережья Лиепая-Клайпеда, где концентрация ПХБ и ДДТ достигает 2,1 и 1,7 мг/к2. Анализ воды Гданьского залива в мае-августе 1974 г. показал, что в настоящее время здесь наблюдается наиболее высокий 
уровень загрязнения хлорорганическими углеводородами, по сравнению с другими районами Балтийского моря. Самые большие концентрации суммарного ДДТ (вместе с метаболитами) - около $3 \mathrm{\mu z/}$ - обнаружены в прибрежных районах Гданьского залива [7]. На открытую часть Балтийского моря, по мнению шведских химиков, влияют сточные воды Стокгольмского архипелага. Например, концентрация ПХБ в воздухе самая высокая в Швеции - до $5,7 \mathrm{~Hz} / \mathrm{M}^{3}\left[{ }^{8,9}\right.$ ]. В Финском и Ботническом заливах таких больших источников локального загрязнения хлорорганическими углеводородами не обнаружено. Концентрации токсикантов в этих районах моря более низкие (табл. 1 и 2).

Полученные данные (табл. 1, 2 и 3) свидетельствуют о циркуляции хлорорганических соединений по всей акватории Балтийского моря. Разная степень накопления этих веществ в рыбах различных популяций указывает на локальное распространение загрязняющих веществ в Балтийском море и его заливах.

\section{Л ИТЕ Р А Т У Р А}

1. International council for the exploration of the sea. - In: Cooperative research report. Denmark, 1977, N 63.

2. Draft report from the Baltic baseline study $1974 / 75$ (рукоп.).

3. Jensen; S., Johnels, A. G., Olsson, M., Otterlind, G. DDT and PCB in herring and cod from the Baltic, the Kattegat and the Skagerrak. - Ambio (special report), $1972, \mathrm{~N} 1$, p. $71-87$.

4. О я в ее р Э. О различении сезонных рас салаки северо-восточной части Балтийского моря по отолитам. - Изв. АН ЭССР, биол., 1962, т. ХІ, № 3, с. 193-207.

5. O j a v e e r, E. Räim - Läänemere heeringas. - Eesti Loodus, 1969, nr. 4, lk. 230235.

6. Роотс О. О., Т ал в ари А. Ф., Янковский Х. И. Газохроматографическое определение запрязнения прибрежных районов Балтийского моря хлорорганическими углеводородами. - В сб.: II Республиканская конференция молодых ученых-химиков. Тезисы докладов, ч. 2. Таллин, 1977, с. 46-47.

7. Trzosins ka, A., S la czka, W., B rzez inska, A. Hydrochemical investigations on the Gdansk basin. - In: 3rd Soviet-Swedish sympos. on the Baltic Sea pollution. Stockholm, 1975.

8. Berrgren, B. PCB and DDT in Baltic sediments. - In: 2rd Soviet-Swedish sympos. on protection of Baltic from pollution. Riga, 1973.

9. Olsson, M., Jensen, S., Renberg, L. PCB in coastal areas of the Baltic. In: PCB conference II. Stockholm, 1972, p. 59-69.

10. Jensen, S., Johnels, A., Olsson, M., Otterlind, G. DDT and PCB in marine animals from Swedish waters. - Nature, 1969 , v. 224!. p. 247-250.

11. K a r p p a ne n, E. O.E.C.D. Study of pesticide residues 1967-68. Helsinki, Finland report, 1970.

Институт термофизики и электрофизики Академии наук Әстонской ССР
Поступила в редакцию $4 / \mathrm{X} 1977$ 